\title{
ANALISIS RISIKO USAHATANI JAGUNG DI KECAMATAN BATANG TUAKA KABUPATEN INDRAGIRI HILIR
}

\author{
Ahmad Sopian Suhendra \\ Program Studi Agribisnis Universitas Islam Indragiri \\ Email: a_suhendra@gmail.com
}

\begin{abstract}
ABSTRAK
Jagung merupakan komoditas pangan kedua setelah padi, sumber kalori atau makanan pengganti beras dan sebagai pakan ternak. Tujuan penelitian ini adalah : (1) untuk menentukan penerimaan dan kelayakan usahatani jagung di Kecamatan Batang Tuaka; (2) untuk menentukan risiko harga usahatani jagung di Kecamatan Batang Tuaka. Metode analisis data yang digunakan : (1) analis biaya (2) analisis penerimaan dan pendapatan (3) analisis risiko. Hasil penelitian menunjukkan bahwa : (1) Besarnya penerimaan usahatani jagung di Kecamatan Batang Tuaka sebesar Rp 6.962.727,00/MT, keuntungan $\mathrm{Rp} 5.321 .464,00 / \mathrm{MT}$ dan R/C 4,24; (2) Nilai koefisien variasi produksi (CVa) sebesar 0,34; batas bawah produksi (La) sebesar 706,57 kg per hektar (2) nilai koefisien variasi harga (CVb) sebesar 0,07; batas bawah harga (Lb) sebesar Rp. 2.795,66 per $\mathrm{kg}$
\end{abstract}

Kata kunci : Jagung, Risiko, Pendapatan, Harga

Corn is the second food commodity after rice, sources of calories or food substitutes for rice and as animal feed. The purposes of this research are : (1) to determine the the revenue and feasibility of corn farming in Subdistrict Batang Tuaka; (2) to determine the roduction risk and price risk of corn farming in Subdistrict Batang Tuaka. Data analysis methods used (1) cost analysis (2) analysis of revenue and income (3) risk analysis. The result of research showed that : (1) The total revenue of corn farming in subdistrict of Batang Tuaka is $R p$ 6.962.727,00/MT, profit $R p$ 5.321.464,00/MT and $R / C$ 4,24; (2) The value of coefficient production variation (CVa) is 0.34 and lower limit of production ( $\mathrm{La}$ ) is $706.57 \mathrm{~kg}$ per hectare (2) The value of coefficient of price variation $(\mathrm{CVb})$ is 0,07 lower limit of price (Lb) is Rp. 2,795.66 per $\mathrm{kg})$.

Keywords : Corn, Risk, Revenue, Price

\section{PENDAHULUAN}

Jagung menjadi salah satu komoditas pertanian yang sangat penting dan saling terkait dengan industri besar. Kondisi ini membuat budidaya jagung memiliki prospek yang sangat menjanjikan, baik dari segi permintaan maupun harga jualnya. Tidak terkecuali dengan Kabupaten Indragiri Hilir, kebutuhan jagung pipil kering juga tinggi untuk kebutuhan pakan.

Luas tanam jagung di Kecamatan Batang sebesar $230 \mathrm{Ha}$, produksi jagung sebesar 540,5 ton, hasil rata-rata per hektar 23,5 ku/Ha. (BPS Indragiri Hilir, 2015). Produksi ini masih tergolong rendah jika dibandingkan dengan produktifitas 
jagung nasional yaitu 51,78 ku/ha (BPS, 2015).

Usahatani jagung pada umumnya merupakan usaha yang memiliki banyak risiko diantaranya adalah risiko produksi dan risiko harga (Hardaker, et al., 1984). Menurut Soekartawi (1993), risiko merupakan suatu keadaan dimana terjadinya peluang kerugian diketahui terlebih dahulu.

Sumber-sumber yang dapat menyebabkan risiko usahatani berasal dari faktor internal dan faktor eksternal. Faktor internal adalah faktor-faktor yang dapat dikendalikan oleh petani. Faktor internal ditunjukkan melalui ketersediaan modal, penguasaan lahan dan kemampuan manajerial, sedangkan faktor eksternal ditunjukkan melalui perubahan iklim/cuaca, serangan hama dan penyakit, harga sarana produksi dan harga output. Faktor eksternal adalah faktor-faktor yang tidak dapat dikontrol atau dikendalikan, karena di luar jangkauan petani.

Risiko produksi dalam usahatani diakibatkan oleh adanya ketergantungan aktivitas pertanian pada alam sehinggapengaruh buruk alam sangat mempengaruhi produksi sedangkan risiko harga dipengaruhi oleh banyaknya produksi jagung yang dihasilkan pada musim tanam tertentu.

$$
\text { Risiko produksi sangat }
$$

mempengaruhi petani dalam pengambilan keputusan. Masalah yang dihadapi di Kecamatan Batang Tuaka antara lain musim kemarau panjang, hujan yang tidak menentu, serangan hama dan penyakit, bencana alam banjir dan kebakaran, atau masalah lain

Usaha pertanian yang erdasarkan pada perencanaan kebutuhan jarang dilakukan oleh petani sehingga sering dijumpai produksi yang melimpah saat panen raya tiba. Akibatnya harga menjadi jatuh dan petani selaku produsen dirugikan. Hal ini mengidentifikasikan adanya faktorfaktor yang menyebabkan petani tidak dapat berproduksi secara optimal. Adanya risiko tersebut berdampak pada pendapatan petani. Perilaku petani terhadap risiko di pengaruhi oleh tingkat pendapatan dan variabel-variabel sosial ekonomi.

Berdasarkan latar belakang tersebut, maka penelitian ini bertujuan untuk:

1. Untuk mengetahui pendapatan, keuntungan dan kelayakan usahatani jagung di Kecamatan Batang Tuaka.

2. Untuk mengetahui risiko produksi dan harga pada usahatani jagung di Kecamatan Batang Tuaka.

\section{METODOLOGI PENELITIAN 2.1. Waktu dan Tempat Penelitian}

Penelitian ini dilakukan di Kecamatan Batang Tuaka Kabupaten Indragiri Hilir Riau. Pemilihan lokasi penelitian dilakukan secara sengaja (purposive) dengan pertimbangan bahwa Kecamatan Batang Tuaka merupakan Kecamatan dengan luas panen terbesar kedua di Kabupaten Indragiri Hilir. (BPS Indragiri Hilir, 2015).

Lokasi penelitian dilakukan di tiga desa yaitu Desa Junjangan, Desa Sungai Raya dan Desa Kuala Sebatu. Pemilihan lokasi penelitian dilakukan dengan pertimbangan dari jumlah petani jagung terbanyak berada pada tiga desa tersebut. Penelitian ini dilaksanakan pada 10 Oktober 2017 sampai dengan 02 Desember 2017.

\subsection{Jenis dan Sumber Data}

Sumber data yang diperlukan pada penelitian ini adalah:

1. Data Primer yaitu data yang diperoleh dan dikumpulkan dari responden melalui pengamatan, 
pencatatan dan wawancara langsung dengan menggunakan daftar pertanyaan (kuisioner) untuk mengetahui luas lahan,biaya produksi, produksi, proses produksi, harga, mengetahui risiko yang terjadi.

2. Data sekunder meliputi data-data yang mendukung seperti penelitian terdahulu, Badan Pusat Statistik (BPS), Badan Penyelenggara Penyuluhan Pertanian, Kehutanan dan Perikanan (BP2KP) Kecamatan Batang Tuaka.

\subsection{Metode Pengambilan Sampel}

Populasi petani jagung dari desa yang dipilih sebesar 95 petani. Untuk menentukan besarnya sampel menggunakan rumus Slovin dengan taraf kesalahan $10 \%$ sebagai berikut.

Dimana :

$$
n=\frac{N}{N e^{2}}
$$

$\mathrm{n}=$ Ukuran Sampel

$\mathrm{N}=$ Ukuran Populasi

$\mathrm{e}=$ Persen Kelonggaran Ketidaktelitian Berdasarkan perhitungan memggunakan rumus diatas diperoleh jumlah sampel sebanyak 49 sampel yang terbagi sesuai persentase jumlah petani disetiap desa sebagai berikut:

Tabel 1. Pembagian Jumlah Sampel di Daerah Penelitian.

\begin{tabular}{lcccc}
\hline No & Desa & Jumlah petani & Persentase & Jumlah sampel \\
\hline 1 & Sungai Junjangan & 30 & $37,0 \%$ & 19 \\
2 & Sungai Raya & 30 & $31,5 \%$ & 15 \\
3 & Kuala Sebatu & 35 & $31,5 \%$ & 15 \\
\multicolumn{2}{l}{ Total } & 95 & $100,0 \%$ & 49 \\
\hline
\end{tabular}

\subsection{Metode Analisis Data}

\section{Analisis Biaya}

Secara matamatis di rumuskan sebagai berikut:

Dimana :

$$
\mathrm{TC}=\mathrm{FC}+\mathrm{VC}
$$

$\mathrm{TC}=$ Total biaya usahatani jagung

(Rp/MT)

$\mathrm{FC}=$ Biaya tetap $(\mathrm{Rp} / \mathrm{MT})$

$\mathrm{VC}=$ Biaya variabel $(\mathrm{Rp} / \mathrm{MT})$

\section{Analisis Penerimaan dan Keuntungan}

Total penerimaan usahatani jagung dapat dihitung dengan mengalikan jumlah produksi jagung yang dihasilkan dengan harga jual jagung. Secara matematis dirumuskan sebagai berikut :

$$
\mathrm{TR}=\mathrm{P} \times \mathrm{Q}
$$

Dimana :

TR $=$ Total penerimaan usahahatani Jagung (Rp/MT)
$\mathrm{Q}=$ Jumlah produksi Jagung yang dihasilkan $(\mathrm{Kg})$

$\mathrm{P}=$ Harga jagung $(\mathrm{Rp} / \mathrm{Kg})$

Keuntungan usahatani jagung dapat dihitung dengan mengurangkan total penerimaan usaha tani jagung dengan total biaya usahatani jagung. Secara matematis dirumuskan sebagai berikut:

$$
\pi=\mathrm{TR}-\mathrm{TC}
$$

Dimana:

$\pi=$ Keuntungan usahatani jagung

$(\mathrm{Rp} / \mathrm{MT})$

$\mathrm{TR}=$ Total penerimaan usahatani jagung (Rp/MT)

$\mathrm{TC}=$ Total biaya usahatani jagung (Rp/MT)

\section{Analisis Kelayakan}

$$
\mathrm{R} / \mathrm{C}=\mathrm{TR} / \mathrm{TC}
$$

Keterangan:

TR = Penerimaan total $(\mathrm{Rp})$ 
$\mathrm{TC}=$ Total biaya $(\mathrm{Rp})$

Kriteria yang digunakan dalam penilaian efisiensi usaha adalah :

- $\quad \mathrm{R} / \mathrm{C}$ Ratio > 1, Usaha dinyatakan layak.

- $\quad \mathrm{R} / \mathrm{C}$ Ratio = 1, Usaha dinyatakan berada pada titik impas.

- $\quad \mathrm{R} / \mathrm{C}$ Ratio < 1, Usaha pengolahan minyak kelapa tidak layak.

\section{Analisis Risiko}

Tingkat risiko usahatani ditentukan berdasarkan nilai koefisien variasi (Pappas dan Hirschey 1995):

Dimana:

$$
C V=\frac{V}{E}
$$

$\mathrm{CV}=$ Koefisiensi variasi

$\mathrm{V}=$ Simpangan baku $(\mathrm{Kg})$

$\mathrm{E}=$ Produksi rata-rata jagung $(\mathrm{Kg})$

Dengan kriteria:

- $\mathrm{Cv}>0,5$ maka usahatani yang dilakukan berisiko mengalami kerugian.

- $\mathrm{CV} \leq 0,5$ maka usahatani yang dilakukan tidak mengalami resiko kerugian ataupun impas.

Nilai CV berbanding lurus dengan risiko yang dihadapi petani, artinya semakin besar nilai CV yang didapat maka semakin besar pula risiko yang harus ditanggung petani, begitu pula sebaliknya. Batas bawah (L) menunjukkan nilai nominal terendah yang mungkin diterima oleh petani dan menunjukkan aman tidaknya usahatani terhadap kemungkinan kerugian. Rumus batas bawah (L) menurut Kadarsan (1995) adalah: :

$$
\mathrm{L}=\mathrm{E}-2 \mathrm{~V}
$$

Dimana:

$\mathrm{L}=$ Batas bawah

$\mathrm{E}=$ Nilai rata-rata

$\mathrm{V}=$ Simpangan baku
Apabila nilai $\mathrm{CV}>0,5$ maka nilai $\mathrm{L}<0$, begitu pula jika nilai $\mathrm{CV} \leq$ 0,5 maka nilai $\mathrm{L} \geq 0$. Hal ini menunjukkan bahwa apabila $\mathrm{CV}>0,5$ atau $\mathrm{L}<0$ maka petani akan rugi, sedangkan jika nilai $\mathrm{CV} \leq 0,5$ atau $\mathrm{L}>$ 0 maka petani akan selalu untung dan apabila nilai $\mathrm{CV}=0$ dan $\mathrm{L}=0$ maka petani akan impas.

\section{HASIL DAN PEMBAHASAN}

\subsection{Karakteristik Responden}

\section{Umur}

Umur merupakan hal yang mempengaruhi petani dalam mengelola usahataninya, karena tingkat umur dapat mempengaruhi daya ingat, produktivitas kerja, pola pikir dalam menerima novasi baru dan pengambilan keputusan dalam menerapkan dan mengembangkan usahataninya.

Tabel 2. Karateristik

Responden

Berdasarkan Umur

\begin{tabular}{cccc}
\hline No & $\begin{array}{c}\text { Umur } \\
\text { (tahun) }\end{array}$ & $\begin{array}{c}\text { Jumlah } \\
\text { (orang) }\end{array}$ & $\begin{array}{c}\text { Persentase } \\
(\%)\end{array}$ \\
\hline 1. & $21-30$ & 1 & 10,00 \\
2. & $31-40$ & 4 & 40,00 \\
3. & $41-50$ & 5 & 50,00 \\
\hline
\end{tabular}

\section{Pendidikan.}

Pendidikan akan sangat mempengaruhi petani dalam mengelola usahataninya karena tingkat pengetahuan seseorang berbeda antara petani yang tingkat pendidikannya lebih tinggi dengan petani yang tingkat pendidikannya yang lebih rendah. 


\begin{tabular}{llcc} 
Tabel 3. Identitas Petani & $\begin{array}{c}\text { Sampel } \\
\text { Berdasarkan } \\
\text { Pendidikan }\end{array}$ & \\
& & & \\
\hline No & Pendidikan & Jumlah \\
& & $\begin{array}{c}\text { Persentase } \\
\text { (orang) }\end{array}$ \\
\hline 1. & SD & 36 & 73,46 \\
2. SLTP & 9 & 18,36 \\
3. SLTA & 4 & 8,18 \\
Jumlah & 49 & 100,00
\end{tabular}

\section{Pengalaman Usahatani}

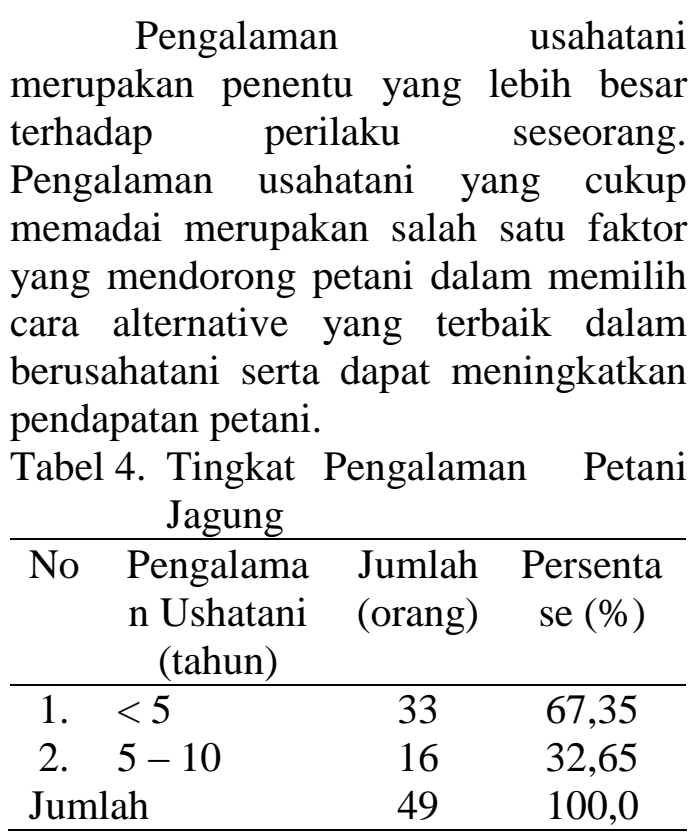

\subsection{Penggunaan Tenaga Kerja}

Sumber tenaga kerja sector pertanian banyak berasal dari keluarga atau disebut tenaga kerja dalam kelarga (TKDK) dan sebagian kecil berasala dari tenaga kerja luar keluarga (TKLK). Curahan tenaga kerja dinyatakan dalam satuan Hari orang Kerja (HOK). Upah yang berlaku di daerah penelitian untuk 1 hari kerja pria (HKP) dengan jam kerja selama 8 jam sebesar Rp. 75.000 sedangkan hari kerja wanita (HKW) dengan jam kerja 5,36 jam. Upah yang berlaku di daerah penelitian untuk 1
HKW sebesar Rp. 70.000. 1 HKW setara dengan 0,67 HKP.

Tabel 5. Penggunaan Tenaga Kerja Berdasarkan Sumber Per Ha

\begin{tabular}{clc}
\hline No & \multicolumn{1}{c}{ Sumber } & Rata-rata \\
\hline 1. & TKDK & \\
a. HKP & 8,09 \\
b. HKW & 4,82 \\
Subtotal & 12,91 \\
2. TKLK & \\
a. HKP & 2,52 \\
b. HKW & 1,33 \\
Subtotal & 3,85 \\
Total & 16,76 \\
\hline
\end{tabular}

\subsection{Analisis Biaya}

Biaya produksi merupakan biaya yang dikeluarkan oleh petani jagung di Kecamatan Batang Tuaka selama melakukan kegiatan usahatani dalam satu kali musim tanam yang meliputi biaya tetap dan biaya tidak tetap. Analisis biaya usahatani jagung di Kecamatan Batang Tuaka disajikan pada Tabel 6 .

\section{Biaya Tetap}

Biaya tetap dalam penelitian ini berasal dari biaya penyusutan alat yang terdiri dari cangkul, parang dan biaya hansprayer. Biaya penyusutan alat dalam penelitian ini sebesar Rp. 74.521/MT.

\section{Biaya Tidak Tetap}

Biaya tidak tetap dalam penelitian ini meliputi biaya yang tenaga kerja, benih dan pestisida. Biaya tenaga kerja sebesar Rp. 1.226.060 biaya benih sebesar Rp. 104.788 dan biaya pestisida sebesar Rp. 235.891.

\section{Total Biaya}

Total biaya diperoleh dari penjumlahan biaya tetap dan biaya tidak tetap sebesar Rp. 1.641.264. 
Tabel 6. Komposisi Biaya Usahatani Jagung di Kecamatan Batang Tuaka per Musim Tanam.

\begin{tabular}{|c|c|c|c|c|}
\hline No & Komponen & Jumlah & $\begin{array}{l}\text { Harga } \\
\text { Satuan } \\
\end{array}$ & $\begin{array}{c}\text { Jumlah } \\
\text { Harga (Rp) }\end{array}$ \\
\hline I & Biaya Tetap & & & \\
\hline 1 & Penyusutan alat & & & \\
\hline $\mathrm{a}$ & Cangkul & & & $11.806,00$ \\
\hline $\mathrm{b}$ & Parang & & & $25.576,00$ \\
\hline \multirow[t]{2}{*}{$\mathrm{c}$} & Hansprayer & & & $37.139,00$ \\
\hline & Subtotal biaya tetap & & & $74.521,00$ \\
\hline II & Biaya tidak tetap & & & \\
\hline \multirow[t]{6}{*}{1} & $\begin{array}{l}\text { Biaya tenaga kerja } \\
\text { TKDK }\end{array}$ & & & \\
\hline & HKP & 8,091 & 75 & $606.818,00$ \\
\hline & HKW & 4,818 & 70 & $337.273,00$ \\
\hline & TKLK & & & \\
\hline & HKP & 2,515 & 75 & $188.636,00$ \\
\hline & HKW & 1,333 & 70 & $93.333,00$ \\
\hline 2 & Benih & 15,00 & 7000 & $104.788,00$ \\
\hline \multirow[t]{9}{*}{3} & Pestisida & & & \\
\hline & Roundup & 1,23 & 80 & $98.181,00$ \\
\hline & Gromoxone & 1,48 & 75 & $111.363,00$ \\
\hline & Decis & 0,23 & 35 & $7.954,00$ \\
\hline & Matador & 0,14 & 25 & $3.409,00$ \\
\hline & Sevin & 0,09 & 35 & $3.181,00$ \\
\hline & Regent & 0,45 & 26.228 & $11.803,00$ \\
\hline & Subtotal biaya tidak tetap & & & $1.566 .742,00$ \\
\hline & Total biaya & & & $1.641 .264,00$ \\
\hline
\end{tabular}

\subsection{Analisis Penerimaan dan Kelayakan Usahatani}

Petani jagung di Kecamatan Batang Tuaka rata-rata menjual hasil panennya dalam bentuk jagung pipil kering. Penerimaan usahatani jagung merupakan hasil perkalian antara jumlah produksi jagung pipil dengan harga jual yang berlaku saat penelitian berlangsung. Hasil analisis penerimaan dan kelayakan usahatani jagung di Kecamatan Batang Tuaka disajikan pada Tabel 7.

Berdasarkan Tabel 7, dapat dilihat bahwa penerimaan usahatani jagung di Kecamatan Batang Tuaka

sebesar Rp.6.962.727/MT dan keuntungan sebesar Rp. 5.321.464/MT.

Sementara itu, untuk kelayakan usahatani dilihat dari nilai R/C. Menurut Soekartawi (1995), apabila nilai R/C $>1$, maka usahatani tersebut layak diusahakan. Hasil analisis menunjukkan bahwa nilai $\mathrm{R} / \mathrm{C}$ usahatani jagung di Kecamatan Batang Tuaka sebesar 4,24. Oleh karena itu, keputusan yang diambil petani tepat dan usahatani jagung tetap diusahakan.

Besarnya nilai $\mathrm{R} / \mathrm{C}$ disebabkan pola pertanaman jagung dilakukan pada lahan bekas pertanaman padi. Setelah panen padi, petani akan merotasi lahannya dengan tanaman jagung 
sehingga biaya penyiapan lahan dapat ditekan karena lahan sudah bersih dan siap tanam. Selain itu sistem pengolahan lahan juga dilakukan dengan minimum tillage dan tidak dilakukan pemupukan kimia. Petani mengandalkan unsur hara dari bahanbahan organic sisa tanaman padi sebelumnya.

Tabel 7. Analisis Penerimaan dan Kelayakan Usahatan Jagung di Kecamatan Batang Tuaka per Musim Tanam

\begin{tabular}{llr}
\hline No & \multicolumn{1}{c}{ Komponen } & \multicolumn{1}{c}{ Jumlah $(\mathrm{Rp})$} \\
\hline 1 & Penerimaan & $6.962 .727,00$ \\
2 & Total Biaya & $1.641 .264,00$ \\
3 & Keuntungan & $5.321 .464,00$ \\
4 & R/C & 4,24 \\
\hline
\end{tabular}

\subsection{Analisis Risiko Produksi}

Pada usahatani risiko atau kerugian adalah hal yang tidak dapat dihindarkan karena semua bentuk usaha pasti terdapat risiko didalamnya. Pada usahatani sendiri ada banyak faktor yang dapat mengakibatkan risiko atau kerugian diantaranya seperti serangan organisme pengganggu tanaman, perubahan iklim dan cuaca, modal, pengalaman berusahatani.

Risiko produksi merupakan risiko yang muncul akibat ketidakpastian jumlah hasil panen yang diperoleh dari suatu usahatani.

Tabel 8. Analisis Risiko Produksi Usahatan Jagung di Kecamatan Batang Tuaka per Musim Tanam

\begin{tabular}{llr}
\hline No & \multicolumn{1}{c}{ Komponen } & \multicolumn{1}{c}{ Nilai } \\
\hline 1 & Rata-rata produksi (Ea) & $2.181,06$ \\
2 & Simpangan baku (Va) & 737,25 \\
3 & Koefisien variasi & 0,34 \\
& (CVa) & \\
4 & Batas bawah produksi & 706,57 \\
& (La) & \\
\hline
\end{tabular}

Tabel 8 menunjukkan bahwa rata-rata produksi petani jagung di Kecamatan Batang Tuaka sebesar $2.181,06 \mathrm{~kg} / \mathrm{ha}$. Besarnya simpangan baku produksi (Va) usahatani jagung di Kecamatan Batang Tuaka sebesar $737,24 \mathrm{~kg} / \mathrm{ha}$ dan koefisien variasi produksi (CVa) 0,34 kg/ha. Koefisien variasi sebesar 0,34 berarti setiap keunutngan satu rupiah, petani memiliki risiko/kehilangan sebesar 0,34 namun usahatani jagung masih menguntungkan.

Nilai batas bawah produksi (La) $706,57 \mathrm{~kg} / \mathrm{ha}$ artinya bahwa produksi jagung terendah di Kecamatan Batang Tuaka agar terhindar dari risiko kerugian sebesar 756,57 kg/ha.

\subsection{Analisis Risiko Harga}

Risiko harga yaitu risiko yang timbul sebagai akibat ketidak pastian dalam perubahan harga. Besarnya risiko harga usahatani jagung di Kecamatan Batang Tuaka dapat dilihat pada Tabel 9.

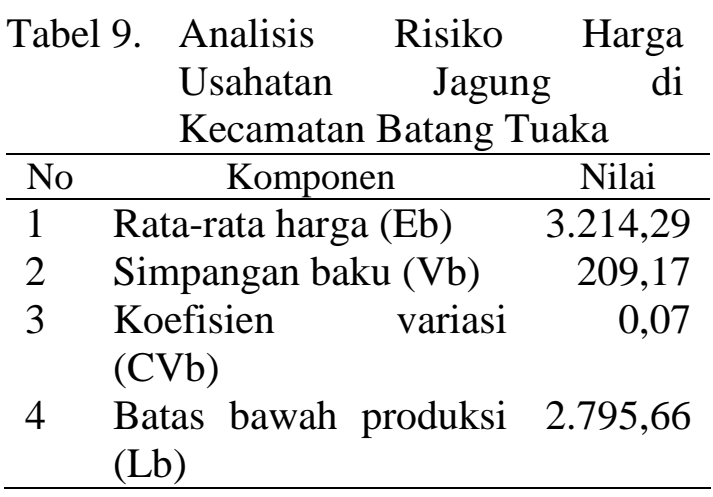

Tabel 9 menunjukkan bahwa rata-rata harga jual jagung oleh petani di Kecamatan Batang Tuaka sebesar Rp. 3.214,29 dan besarnya simpangan baku harga (Vb) Rp. 209,17 serta koefisien variasi harga $(\mathrm{CVb})$ hal ini berarti bahwa besarnya peluang risiko harga yang mungkin dihadapi petani jagung sebesar 0,07 namun usahatani jagung masih menguntungkan. 
Nilai koefisien variasi harga (CVb) 0,07 yang Nilai batas bawah harga (Lb) sebesar Rp. 2.795,66 artinya kemungkinan harga terendah yang diterima petani jagung yang dapat menyebabkan terjadinya risiko adalah sebesar Rp 2.795,66 per kg.

\section{KESIMPULAN}

Berdasarkan penelitian yang dilakukan, maka dapat disimpulkan bahwa:

1. Besarnya penerimaan usahatani jagung di Kecamatan Batang Tuaka sebesar $\mathrm{Rp}$ 6.962.727,00/MT, keuntungan $\mathrm{Rp} \quad 5.321 .464,00 / \mathrm{MT}$ dan R/C 4,24.

2. Nilai koefisien variasi produksi (CVa) sebesar 0,34 dengan batas bawah produksi (La) sebesar 706,57 $\mathrm{kg} / \mathrm{ha}$. Hasil tersebut menunjukkan bahwa petani jagung memiliki peluang kehilangan produksi sebesar 0,34 namun usahatani jagung masih menguntungkan dan kemungkinan produksi terendah yang dapat menyebabkan risiko sebesar 756,57 $\mathrm{kg}$ per hektar.

3. Nilai koefisien variasi (CV) risiko harga sebesar 0,07 dengan batas bawah (L) sebesar Rp. 2.795,06. Hasil tersebut menunjukkan bahwa besarnya peluang risiko harga yang mungkin dihadapi petani jagung sebesar 0,07 namun usahatani jagung masih menguntungkan dan kemungkinan harga terendah yang diterima petani jagung yang dapat menyebabkan terjadinya risiko adalah sebesar Rp 2.795,66 per kg.

\section{DAFTAR PUSTAKA}

Badan Pusat Statistik Indragiri Hilir. 2015. Luas Panen, Produksi dan Produktivitas Jagung dan Kedelai Menurut Kecamatan di Kabupaten Indragiri Hilir.

Naftaliasari, Tri; Zainal Abidin dan Umi Klasum. 2015. Analisis Risiko Usahatani Kedelai di Kecamatan Raman Utara Kabupaten Lampung Timur. JIIA Volume 3 No 2. Hal 148 - 156.

Pappas JM dan Hierschey M. 1995. Ekonomi Managerial Edisi Keenam Jilid II. Bina Rupa Aksara.Jakarta.

Saptana, Daryanto A, Daryanto HK dan Kuntjoro. 2010. Strategi Manajemen Resiko Petani Cabai Merah Pada Lahan Sawah Dataran Rendah di Jawa Tengah. Jurnal Manajemen dan Agribisnis, 7(2): 115-131.

Soekartawi. 1993. Risiko dan Ketidakpastian dalam Agribisnis, Teori dan Aplikasi. Rajagrafindo Persada. Jakarta Soekartawi. 1995. Analisis Usahatani. UI Press. Jakarta.

UPT BP2KP Batang Tuaka. Data Kelompok Tani dan Gabungan Kelompok Tani Kecamatan Batang Tuaka Tahun 2015. 